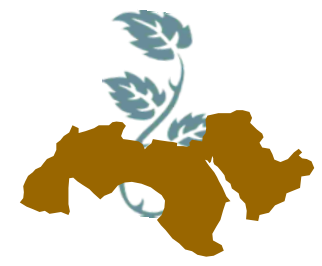

\title{
GENETIC ASSESSMENT IN SOME MEDICINAL PLANTS UTILIZING MOLECULAR MARKERS
}

\author{
Samar A. Salah ${ }^{1}$, Enjy M. Masoad ${ }^{1}$, El-bakry² A. and Ibrahim² S.A. \\ 1- Genetic Resources Dept., Environment Division, Desert Research Center, Cairo, Egypt \\ 2- Genetic Dept., Fac. of Agric., Ain Shams Univ., P.O. Box 68 Hadayek Shoubra 11241, Cairo, \\ Egypt
}

Keywords: Medicinal plants, Solanaceae, Genetic diversity, ISSR technique

\begin{abstract}
The interest in medicinal plants is not only due to the fact that it is a source of food additives, but it is also a major source of medicines. Medical plants contain many important vital ingredients used in the treatment of many diseases. Therefore, medicinal plants are considered a safe source of medical drugs. Many medicinal plants have a significant economic importance to increase their demand. The plant families include many families, such as solanaceae family, which is one of the largest plant families with more than 3000 plant species And the plants of this family contains many important biological components and because of its importance, it was necessary to study and identify these plants by making fingerprinting, detect the molecular genetic markers for this family, study the genetic diversity of these species and determine the relationships between species of this family by using genetic techniques such as the technique of Inter simple sequence repeat (ISSR). The results obtained in the five solanaceae species (Lycium shwaii, Hyoscyamus muticus, Solanum nigrum from Northwestern coast, Solanum nigrun from Saint Katherine, and Nicotiana gluca) indicated that, 6 primers were applied. The HB15 primer which gave 12 bands, showed the highest polymorphism $58.33 \%$, and the $49 \mathrm{~A}$ primer, which gave 6 bands gave a lowest polymrphism 16.66\% between the used plants populations, these results mean that ISSR technique is an powerful tool to make genetic diversity assessment for species.
\end{abstract}

\section{INTRODUCTION}

Over the past decade, herbal medicine has become a topic of global importance, making an impact on both world health and international trade. Medicinal plants continue to play a central role in the health care system of large proportions of the human's population. This is particularly true in developing countries, where herbal medicine has along and uninterrupted history of use. Recognition and development of the medicinal and economic benefits of these plants are on the increase in both developing and industrialized nations. Continuous usage of herbal medicine by a large proportion of the population in the developing countries is largely due to the high cost of western pharmaceuticals and healthcare, (Akerele, 1988 and WHO, 1998). Family solanaceae is one of the most intriguing plant families in the world not only because it is one of the largest families in plant kingdom with more than 3,000 species, but also this family consists of some plants as Atropa, Datura, and Hyoscyamus that are important from medicinal point of view. This importance is due to their tropan alkaloid content (Evans, 1979). Genetic fingerprinting has been accomplished traditionally through the use of isozymes, total seed protein and more recently through various types of molecular DNA markers. However, DNA-based markers provide powerful tools for discerning variations within crop germplasm and for studying evolutionary relationships. Among molecular markers, randomly amplified polymorphic DNAs (RAPDs) have been extensively used in genetic research owing to their speed and simplicity.

Assessment of genetic diversity and relationships within and among crop species and their wild relatives is essential not only for basic studies on 
evolution but also for informed utilization and protection of plant genetic resources (Rao and Hodgkin, 2002; Barcaccia, 2009; Brozynska et al 2015).

Rajora and Mosseler (2001) found out that, a central objective of genetic resources conservation is to maintain genetic integrity and natural levels of genetic diversityand to enhance genetic diversity in population and species where it has been eroded. $\mathrm{He}$ further stated that genetic diversity is essential for the long term survival of the species by populations because it provides the raw material for adoption and evolution, especially when environmental conditions have changed.

\section{MATERIALS AND METHODS}

\section{1- Materials}

\section{Plant Materials}

The present study was carried out at Agriculture Research Center (ARC). Leaves of the five medicinal plants (Lycium shawii, Solanum nigrum , Nicotiana glauca, Hyoscyamus muticus ) are collected from their nature habitats (North western coast and saint Catherin). These species were selected as a study site because they contain vital components, most important of which are alkaloids which have many medicinal uses.

\section{2- Method}

\section{Inter Simple Sequence Repeat ISSR}

Genomic DNA was extracted from $0.12 \mathrm{~g}$ of fresh leaf material from five randomly selected plants per accession using a Plant total DNA GPB Mini Kit (Geno Plast Biochemicals, Poland) according to the manufacturer's instructions. DNA quality and quantity were established by spectrophotometric measurements and agarose gel electrophoresis. Only samples of high quality were used for ISSR-PCR. ISSR-PCR amplifications were performed in reaction volumes of $25 \mu \mathrm{L}$, containing 30 ng of genomic DNA template, $0.1 \mathrm{U} / \mu \mathrm{L}$ Taq DNA polymerase, $4 \mathrm{mM} \mathrm{MgCl}$, $0.5 \mathrm{mM}$ of each dNTPs, $10 \mu \mathrm{M}$ primer, and sterile deionized water. Reactions were performed using a T100 Thermal Cycler (Bio-Rad, Poland) under the following conditions: initial denaturation at $94{ }^{\circ} \mathrm{C}$ for $5 \mathrm{~min}$, followed by 40 cycles of $94^{\circ} \mathrm{C}$ for $1 \mathrm{~min}$, annealing at $47.1-$ $67.2^{\circ} \mathrm{C}$ (depending on the primer sequence) for 1 $\mathrm{min}$, and $72{ }^{\circ} \mathrm{C}$ for $2 \mathrm{~min}$. The last cycle was fol- lowed by a final extension step of $7 \mathrm{~min}$ at $72{ }^{\circ} \mathrm{C}$. Thirty-nine ISSR primers (Genomed, Poland; previously reported by Rewers and Jedrzejczyk, 2016) were tested, out of which 28 generated stable band patterns and five primers were selected for further studies (Supporting Information, Table (1). All reactions with the selected primers were repeated twice. Amplification products were separated using $1.5 \%(\mathrm{w} / \mathrm{v})$ agarose gel electrophoresis. A DNA ladder of 3000 bp was used to determine the size of the fragments. The bands were visualized using GelDoc XR+ (Bio-Rad). The ISSR bands were counted using a binary scoring system that recorded the presence or absence of bands as 1 and 0 , respectively. The number of monomorphic and polymorphic amplification products generated by each primer was determined. The polymorphism information content (PIC) was calculated according to Ghislain et al (1999). Estimates of genetic distances were calculated according to Nei and Li (1979) and a dendrogram was constructed using the unweighted pair group method with arithmetic average (UPGMA) by the Treecon v. 3.1 program (Van de Peer and De Wachter, 1994). Statistical support of the branches was tested with bootstrap analysis using 2000 replicates. The distance matrix was used for principal coordinate analysis (PCoA).

\section{RESULTS AND DISCUSSION}

In the present study, the genetic variability and relationships of six different natural medicinal plants (Lycium shawii, Solanum nigrum, Nicotiana glauca, Hyoscyamus muticus ) that collected from North western coast, and (Lycium shawii, Solanum nigrum, Nicotiana glauca, Hyoscyamus muticus ) that collected from Saint Catherin have been studied based on ISSR molecular markers .

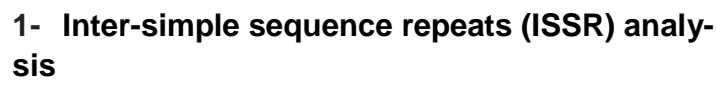
sis

Understanding the level of genetic diversity and the population genetic structure is important for medicinal plant species, because this allows the establishment of effective and efficient conservation practices and can guide choices for their genetic management. Nowadays, it is possible to use several molecular methods to analyze the genetic variability in plant species. One of them, intersimple sequence repeat polymorphisms (ISSR), have been successfully used for genetic analysis of medicinal plants, as they require no prior 
knowledge of the DNA sequence and are universally applicable as dominant markers (Sa et al 2011) for rapid exploratory work on new species. Furthermore, ISSRs have been demonstrated to be useful for the analysis of inter- and/or intraspecific genetic diversity in different Gentianaceae species (Ge et al 2005; Zhang et al 2007; Yang et al 2011; Zheng et al 2011).

Table 1. List of the primer names and their nucleotide sequences used in the study

\begin{tabular}{|l|l|l|}
\hline No. & Name & \multicolumn{1}{c|}{ Sequence } \\
\hline 1 & 44A & 5' CTC TCT CTC TCT CTC TAC 3 \\
\hline 2 & 49A & 5' CAC ACA CAC ACA AG 3 \\
\hline 3 & 49B & 5' CAC ACA CAC ACA GG 3 \\
\hline 4 & 98B & 5' CAC ACA CAC ACA GT 3 \\
\hline 5 & HB8 & 5' GAG AGA GAG AGA GG 3’ \\
\hline 6 & HB15 & 5' GTG GTG GTG GC 3 \\
\hline
\end{tabular}

In the present study, many of primers were used to deffrentiate between the five plants (Lycium shawii, Solanum nigrum, Nicotiana glauca, Hyoscyamus muticus) which collected from two different locations (North west coast, Saint Catherine). However, only six primers (44A-49A-49B98B-HB8-HB15). Shown in Table (2) gave reproducible results and were reprted as follow:

The PCR products of primer 44A are illustrated in Fig. (1) and Table (3). This primer produced three (3) bands ranging from $1500 \mathrm{pb}$ to $500 \mathrm{pb}$. This primer produced two common bands in all five plants ( from the all different locations) with molecular sizes 1000 and $500 \mathrm{pb}$.

The PCR products of primer 49A are illustrated in Fig. (1) and Table (3). This primer produced six
(6) bands ranging from $4000 \mathrm{pb}$ to $500 \mathrm{pb}$. This primer produced five common bands in all five plants (from the different locations) with molecular sizes 3000 and $500 \mathrm{pb}$.

He PCR products of primer49B are illustrated in Fig. (1) and Table (3). This primer produced Thirteeen (13) bands ranging from $2000 \mathrm{pb}$ to 100 $\mathrm{pb}$. This primer produced eight (8) common bands with molecular markers $(900 \mathrm{pb}-800 \mathrm{pb}-700 \mathrm{pb}-$ $600 \mathrm{pb}-500 \mathrm{pb}-400 \mathrm{pb}-300 \mathrm{pb}-$ and 200pb)in all five plants (from different locations). On the other hand Nicotiana gluca has two common bands with molecular sizes with $2000 \mathrm{pb}$ and 1500 pb. While Solanum nigrum from (North coast)has one specific band with molecular size $100 \mathrm{pb}$.

The PCR products of primer98B are illustrated in Fig. (1) and Table (3). This primer produced three (3) bands ranging from $1500 \mathrm{pb}$ to $500 \mathrm{pb}$. This primer produced two common bands in all five plants (from different locations) with molecular sizes $1000 \mathrm{pb}$ and $500 \mathrm{pb}$.

The PCR products of primer HB8 are illustrated in Fig. (1) and Table (3). This primer produced nine (9) bands ranging from $2000 \mathrm{pb}$ to $500 \mathrm{pb}$. Nicotiana Gluca has two positive specific bands with molecular sizes $1200 \mathrm{pb}$ and $700 \mathrm{pb}$, While Lycium shawii has one positive specific band with molecular size $500 \mathrm{pb}$.

The PCR products of primer HB15 are illustrated in Fig. (1) and Table (3). This primer produced twelve (12) bands ranging from $1,500 \mathrm{pb}$ to 100 $\mathrm{pb}$. This primer produced four (4) common bands with molecular sizes $(600 \mathrm{pb}-400 \mathrm{pb}-300 \mathrm{pb}-$ $100 \mathrm{pb}$ ). Solanum nigrum from (North coast) has two positive specific bands with molecular sizes $1,500 \mathrm{pb}$ and 1,200 pb , While Hyoscyamus muticus has one specific band with molecular size 700 $\mathrm{pb}$. 
Table 2. Amplified fragments obtained from the DNAs of the five plants using RAPD-PCR technique

\begin{tabular}{|c|c|c|c|c|c|c|c|c|}
\hline $\begin{array}{c}\text { AF } \\
\text { of } \\
\text { RAPD } \\
\text { primers }\end{array}$ & $\begin{array}{l}\text { Band } \\
\text { No. }\end{array}$ & $\begin{array}{l}\text { Lycium } \\
\text { shawii }\end{array}$ & $\begin{array}{c}\text { Solanum } \\
\text { nigrum } \\
\text { (North } \\
\text { coast) }\end{array}$ & $\begin{array}{c}\text { Solanum } \\
\text { nigrum } \\
\text { (Saint } \\
\text { Catherine) }\end{array}$ & $\begin{array}{c}\text { Nicotiana } \\
\text { glauca }\end{array}$ & $\begin{array}{c}\text { Hyoscyamus } \\
\text { muticus }\end{array}$ & $\begin{array}{l}\text { M.S } \\
\mathrm{Pb}\end{array}$ & M+M- \\
\hline \multirow[t]{2}{*}{ 44A } & $\begin{array}{l}1 \\
2 \\
3 \\
\end{array}$ & $\begin{array}{l}1 \\
1 \\
1 \\
\end{array}$ & $\begin{array}{l}0 \\
1 \\
1 \\
\end{array}$ & $\begin{array}{l}1 \\
1 \\
1 \\
\end{array}$ & $\begin{array}{l}0 \\
1 \\
1 \\
\end{array}$ & $\begin{array}{l}0 \\
1 \\
1 \\
\end{array}$ & \begin{tabular}{|l|}
1500 \\
1000 \\
500 \\
\end{tabular} & \\
\hline & Total & 3 & 2 & 3 & 2 & 2 & & \\
\hline \multirow[t]{2}{*}{ 49A } & $\begin{array}{l}11 \\
2 \\
3 \\
4 \\
5 \\
6\end{array}$ & $\begin{array}{l}1 \\
1 \\
1 \\
1 \\
1 \\
1\end{array}$ & $\begin{array}{ll}1 \\
1 \\
1 \\
1 \\
1 \\
1\end{array}$ & $\begin{array}{ll}1 \\
1 \\
1 \\
1 \\
1 \\
1\end{array}$ & $\begin{array}{l}0 \\
1 \\
1 \\
1 \\
1 \\
1\end{array}$ & $\begin{array}{l}0 \\
1 \\
1 \\
1 \\
1 \\
1\end{array}$ & \begin{tabular}{|l|}
4000 \\
3000 \\
2000 \\
1,500 \\
1000 \\
500 \\
\end{tabular} & \\
\hline & Total & 6 & 6 & 6 & 5 & 5 & & \\
\hline \multirow[t]{2}{*}{ 49B } & \begin{tabular}{|l}
1 \\
2 \\
3 \\
4 \\
5 \\
6 \\
7 \\
7 \\
8 \\
9 \\
10 \\
11 \\
12 \\
13 \\
\end{tabular} & $\begin{array}{l}0 \\
0 \\
1 \\
1 \\
1 \\
1 \\
1 \\
1 \\
1 \\
1 \\
1 \\
1 \\
0\end{array}$ & \begin{tabular}{|ll}
0 & \\
0 & \\
1 \\
1 \\
1 \\
1 \\
1 \\
1 \\
1 \\
1 \\
1 \\
1 \\
1 \\
1 \\
1 \\
\end{tabular} & $\begin{array}{ll}0 & \\
1 \\
1 \\
1 \\
1 \\
1 \\
1 \\
1 \\
1 \\
1 \\
1 \\
1 \\
1 \\
1 \\
0\end{array}$ & $\begin{array}{l}1 \\
1 \\
1 \\
1 \\
1 \\
1 \\
1 \\
1 \\
1 \\
1 \\
1 \\
1 \\
0 \\
\end{array}$ & $\begin{array}{l}0 \\
0 \\
0 \\
0 \\
1 \\
1 \\
1 \\
1 \\
1 \\
1 \\
1 \\
1 \\
0\end{array}$ & \begin{tabular}{|l|}
2000 \\
1,500 \\
1,200 \\
1,031 \\
900 \\
800 \\
700 \\
600 \\
500 \\
400 \\
300 \\
200 \\
100 \\
\end{tabular} & $\begin{array}{l}\mathrm{M}+ \\
\mathrm{M}- \\
\mathrm{M}-\end{array}$ \\
\hline & Total & 10 & 11 & 11 & 12 & 9 & & \\
\hline \multirow[t]{2}{*}{ 98B } & $\begin{array}{l}1 \\
2 \\
3\end{array}$ & $\begin{array}{l}1 \\
1 \\
1\end{array}$ & $\begin{array}{l}1 \\
1 \\
1\end{array}$ & $\begin{array}{l}0 \\
1 \\
1\end{array}$ & $\begin{array}{l}0 \\
1 \\
1\end{array}$ & $\begin{array}{l}1 \\
1 \\
1\end{array}$ & \begin{tabular}{|l|}
1,500 \\
1,000 \\
500
\end{tabular} & \\
\hline & Total & 3 & 3 & 2 & 2 & 3 & & \\
\hline \multirow[t]{2}{*}{ HB8 } & $\begin{array}{l}1 \\
2 \\
3 \\
4 \\
5 \\
6 \\
7 \\
8 \\
9\end{array}$ & $\begin{array}{l}1 \\
1 \\
0 \\
0 \\
1 \\
0 \\
0 \\
0 \\
1\end{array}$ & $\begin{array}{l}1 \\
1 \\
0 \\
0 \\
0 \\
0 \\
0 \\
1 \\
0\end{array}$ & $\begin{array}{l}0 \\
0 \\
0 \\
0 \\
1 \\
1 \\
0 \\
0 \\
0 \\
0\end{array}$ & $\begin{array}{l}1 \\
1 \\
1 \\
0 \\
0 \\
0 \\
1 \\
0 \\
0\end{array}$ & $\begin{array}{l}1 \\
1 \\
0 \\
0 \\
0 \\
0 \\
0 \\
1 \\
0\end{array}$ & \begin{tabular}{|l|}
2000 \\
1,500 \\
1,200 \\
1,031 \\
900 \\
800 \\
700 \\
600 \\
500 \\
\end{tabular} & $\begin{array}{l}\mathrm{M}- \\
\mathrm{M}- \\
\mathrm{M}+ \\
\\
\mathrm{M}_{+} \\
\mathrm{M}_{+} \\
\mathrm{M}_{+}\end{array}$ \\
\hline & Total & 4 & 3 & 2 & 4 & 3 & & \\
\hline HB15 & \begin{tabular}{|l}
1 \\
2 \\
3 \\
4 \\
5 \\
6 \\
7 \\
8 \\
9 \\
10 \\
11 \\
12 \\
\end{tabular} & $\begin{array}{l}0 \\
0 \\
1 \\
0 \\
1 \\
0 \\
1 \\
0 \\
1 \\
1 \\
1 \\
1 \\
7\end{array}$ & \begin{tabular}{|l}
1 \\
1 \\
1 \\
0 \\
0 \\
0 \\
1 \\
1 \\
1 \\
1 \\
1 \\
1 \\
\end{tabular} & $\begin{array}{l}0 \\
0 \\
1 \\
0 \\
0 \\
0 \\
1 \\
1 \\
1 \\
1 \\
0 \\
1 \\
\end{array}$ & $\begin{array}{l}0 \\
0 \\
0 \\
0 \\
1 \\
0 \\
1 \\
1 \\
1 \\
1 \\
1 \\
1 \\
1 \\
\end{array}$ & $\begin{array}{l}0 \\
0 \\
1 \\
0 \\
0 \\
1 \\
1 \\
1 \\
1 \\
1 \\
1 \\
1 \\
\end{array}$ & \begin{tabular}{|l|}
1,500 \\
1,200 \\
1,031 \\
900 \\
800 \\
700 \\
600 \\
500 \\
400 \\
300 \\
200 \\
100 \\
\end{tabular} & $\begin{array}{l}\text { M+ } \\
\text { M+ } \\
M-\end{array}$ \\
\hline
\end{tabular}



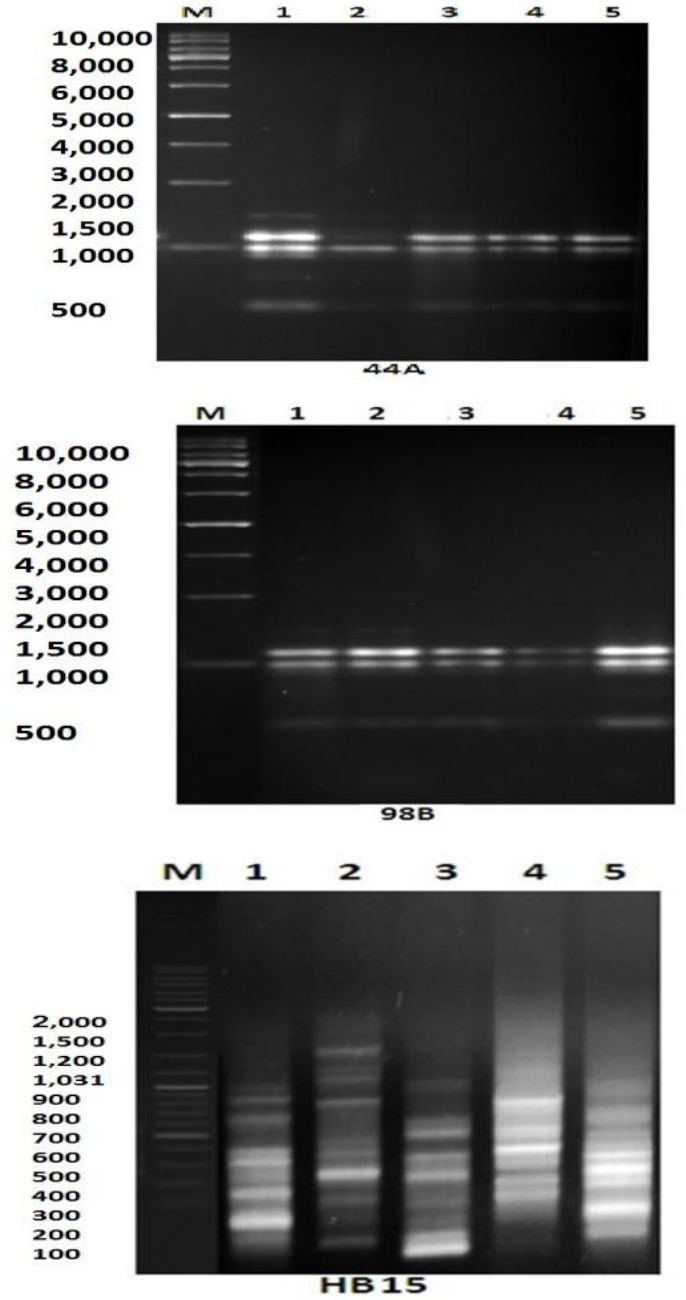

Fig. 1. ISSR banding patterns of the five species amplified with six arbitrary primers

Table 3. Amplification results of the five ISSR primers for the five solanaceae plants genotypes tested

\begin{tabular}{|c|c|c|c|c|c|c|c|c|c|c|c|c|c|c|}
\hline \multirow{3}{*}{ Primers } & \multirow{3}{*}{ TAF } & \multirow{3}{*}{ PB } & \multirow{3}{*}{$\mathbf{P} \%$} & \multicolumn{10}{|c|}{ Genotypes } & \multirow{3}{*}{ TSM } \\
\hline & & & & \multicolumn{2}{|c|}{ G1 } & \multicolumn{2}{|c|}{ G2 } & \multicolumn{2}{|c|}{ G3 } & \multicolumn{2}{|c|}{ G4 } & \multicolumn{2}{|c|}{ G5 } & \\
\hline & & & & AF & SM & AF & SM & AF & SM & AF & SM & AF & SM & \\
\hline $44 \mathrm{~A}$ & 3 & 1 & $33.33 \%$ & 3 & 0 & 2 & 0 & 3 & 0 & 2 & 0 & 2 & 0 & 0 \\
\hline $49 A$ & 6 & 1 & $16.66 \%$ & 6 & 0 & 6 & 0 & 6 & 0 & 5 & 0 & 5 & 0 & 0 \\
\hline $49 B$ & 13 & 5 & $38.46 \%$ & 10 & 0 & 11 & 0 & 11 & 0 & 12 & 1 & 9 & 2 & 3 \\
\hline $98 \mathrm{~B}$ & 3 & 1 & $33.33 \%$ & 3 & 0 & 3 & 0 & 2 & 0 & 2 & 0 & 3 & 0 & 0 \\
\hline HB8 & 9 & 8 & $88.88 \%$ & 4 & 1 & 3 & 0 & 2 & 3 & 4 & 2 & 3 & 0 & 6 \\
\hline HB15 & 12 & 7 & $58.33 \%$ & 7 & 1 & 9 & 2 & 6 & 1 & 7 & 1 & 8 & & 5 \\
\hline
\end{tabular}

G1: Lycium shwaii G2: Solanum nigrum (Northwestern coast)

G3: Solanum nigrum (Saint Katherine) G4:Nicotiana gluca G5: Hyoscyamus muticus

$\mathrm{TAF}=$ Total number of amplified fragments

$\mathrm{PB}=$ polymorphic bands

$\mathrm{P} \%=$ Polymorphism percentage

$\mathrm{AF}=$ Amplified fragments / genotype

$\mathrm{SM}=$ Genotype - Specific marker including either the presence or absence of a given band

$\mathrm{TSM}=$ Total number of specific markers 
The present study aimed to survey the molecular analysis to assess the genetic variation of five different plant species from family solanaceae (Lycium shwaii, Solamnum nigrum, Hyoscyamus muticus, Nicotiana gluca) from North western coast and (Lycium shwaii, Solanum nigrum, Hyoscyamus muticus) from Saint Catherin. At the molecular level ISSR marker was applied to assesss the DNA fingerprinting between (Lycium shwaii, Solanum nigrum from north western coast, Solanum nigrum from Saint Catherin, Hyoscyamus muticus, Nicotiana gluca). For ISSR analysis six ISSR analysis were used to differentiate between the five plants. The results obtained from ISSR analysis resulted in $3,6,13,3,9$ and 12 total bands for each species Lycium shwaii, Solanum nigrum from north western coast, Solanum nigrum from Saint Catherin, Hyoscyamus muticus, and Nicotiana gluca. Elkholy et al (2011) supported our results by using the same technique to evaluate Genetic variability in Nepeta septemcrenata populations from six locations in Saint Catherin protectorate. Also Sarkhaill et al (2014) and Solyman and Alkawni (2014) agree with this results.

\section{REFERENCES}

Akerele, O. 1988. Medecinal plants and primary health care: An agenda for action. Fitoterapia., 59, 355-363.

Barcaccia, G. 2009. Molecular markers for characterizing and conserving crop plant germplasm. In: Jain S M, Brar D S. Molecular Techniques in Crop Improvement. Dordrecht, Netherlands: Springer, pp. 231-254.

Brozynska M., Furtado A. and Henry R.J. 2015. Genomics of crop wild relatives: Expanding the gene pool for crop improvement. Plant Biotechnol, J. 14(4), 1070-1085.

Elkholy, M.A., Mansour, M. and Omar, K. 2011. Genetic variability of Nepeta septemcrenata Benth. (Lamiaceae) Assessed by RAPD Markers. New York Sci. J. 4(6), 97-105.

Evans. W.C. 1979. In: Biology and taxonomy of the solanaceae. ED. Skelding. Academic prees, London, UK, pp. 241-254.

Ge, X.J., Zhang, L.B., Yuan, Y.M., Hao, G, 2005. Strong genetic differentiation of the eastHimalayan Megacodon stylophorus (Gentianaceae) detected by inter-simple sequence repeats (ISSR). Biodivers. Conserv, 14, 849861.
Ghislain, M., Zhang, D., Fajardo, D., Huamán, Z. and Hijmans, R.J. 1999. Marker-assisted sampling of the cultivated Andean potato Solanum phureja collection using RAPD markers. Genet Resour Crop Ev., 46, 547-555.

Nei, M. and Li, W.H. 1979. Mathematical model for studying genetic variation in terms of restriction endonucleases. P Natl Acad Sci. USA 76, 5269-5273.

Rajora, O.P. and Mosseler, A. 2001. Challenges and opportunities for conservation of forest genetic resources. Euphytica, 118, 197-212.

Rao, V.R. and Hodgkin, T. 2002. Genetic diversity and conservation and utilization of plant genetic resources. Plant Cell Tiss Organ, 68, 1-19.

Rewers, M. and Jedrzejczyk, I. 2016. Genetic characterization of Ocimum genus using flow cytometry and inter-simple sequence repeat markers. Lnd Crop Prod 91, 142-151.

Sa, O., Pereira, J.A. and Baptista, P. 2011. Optimization of DNA extraction for RAPD and ISSR analysis of Arbutus unedo L. leaves. Int. J. Mol. Sci., 12, 4156-4164.

Solyman, E. and Alkowni, R. 2014. RAPD for Assessment of Thymes Genetic Diversity in Palestine. Palestine Technical Univ., Research J. 2(2), 01-08.

Van de Peer, Y. and De Wachter, Y. 1994. TREECON for Windows: a software package for the construction and drawing of evolutionary trees for the Microsoft Windows environment. Comput Appl. Biosci 10, 569-570.

WHO, 1998. Regulatory situation of herbal medicines. A worldwide review, Geneva, Switzerland. pp. 1-5.

Yang, L.C., Zhou, G.Y. and Chen, G.C. 2011. Genetic diversity and population structure of Swertia tetraptera (Gentianaceae), an endemic species of Qinghai-Tibetan plateau. Biochem. Syst. Ecol. 39, 302-308.

Zhang, X.L., Yuan, Y.M. and Ge, X.J. 2007. Genetic structure and differentiation of Gentiana atuntsiensis WW Smith and G. striolata TN Ho (Gentianaceae) as revealed by ISSR markers. Bot. J. Linn. Soc. 154, 225-232.

Zheng, P., Zhang, K. and Wang, Z. 2011. Genetic diversity and gentiopicroside content of four Gentiana species in China revealed by ISSR and HPLC methods. Biochem. Syst. Ecol. 39, 704-710. 
التقييم الوراثى فى بعض النباتات الطبية بإستخدام الواسمات الجزيئية

[148]

سمر أحمد صلاح' - أنجي محمود مسعود 1 - أثرف البكرى2 - سمير عبد العزيز ابراهيم²

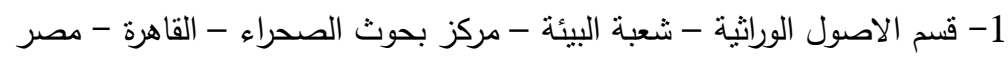

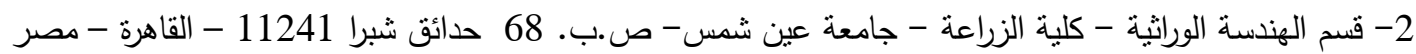

هذه العائله على العديد من المكونات الحيويه الهامه

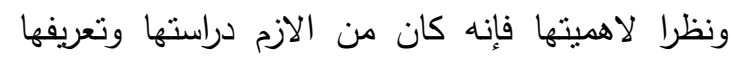

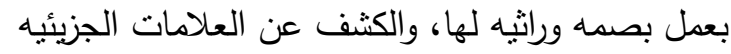

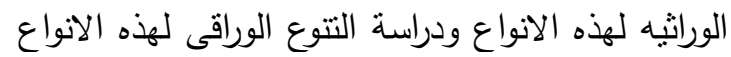

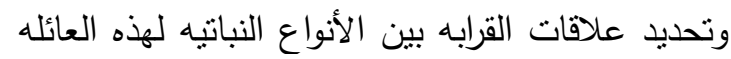

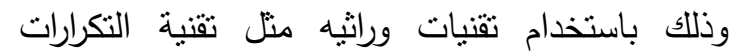
المتتابعة البينية البسيطة حيث أن النتائج المستخدمه

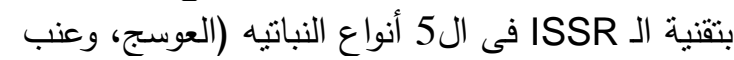

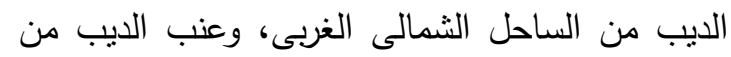

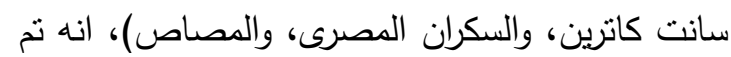

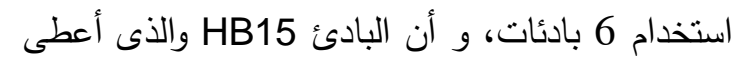

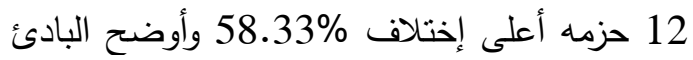

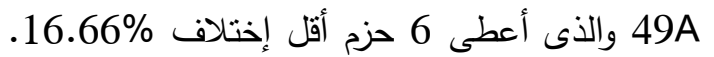
نتائج هذه الدراسه تعنى ان هذه الته التقنيه هى أداه قويه لعمل تقييم للتنوع الوراثى بين الانواع.
الكلمات الدالة: النباتات الطبيه، العائله الباذنجانيه،

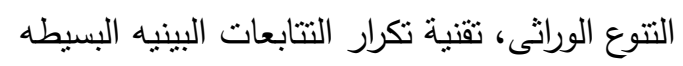

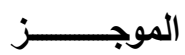

إن الاهتمام بالنباتات الطبيه لا يرجع فقط انها

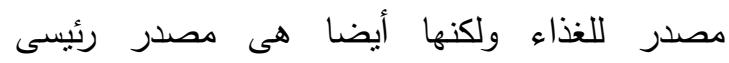
للحصول على الادويه حيث تحنوى النباتات الطبيه

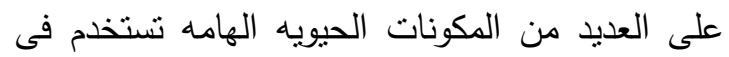

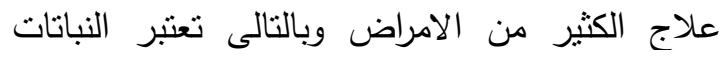

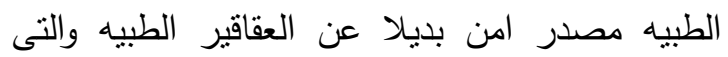
ينتج عن استخدامها اثار جانبيه عديده ، وعليه النباتات الطيات الطيه الطبيه لها أهيه إقتصاديه كبيره لزيادة الطلب عليهان النيها.

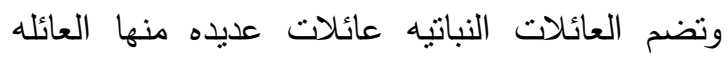
الباذنجانيه وهى واحده من أكبر العائلات النباتيه حيث انثانث

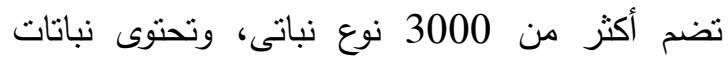


2009

مجلة اتحاد الجامعات العربية

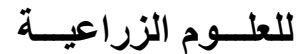

جامعة عين شمس المراع ، القاهرة

مجلد(26)، عدد (2C)، عدد خاص ، 2003 - 2009، 2018، 2018

تحكيم: 1.د عبد الفتاح عبد القادر عوض

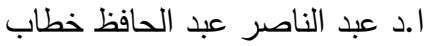

